\title{
Islamic Radicalism Network in The City of Palu
}

\author{
Gani Jumat ${ }^{1}$ \\ \{gani.jumat@gmail.com $\left.{ }^{1}\right\}$ \\ Institut Agama Islam Negeri Palu, Indonesia
}

\begin{abstract}
This article discusses Islamic radicalism in Palu City, networks and political alliances, as well as people's responses to their existence. This paper is limited to two main problems; first, how radical Islamic political activities and alliances in the city of Palu, second, how the community's response to the radical Islamic network. In network theory there are two important elements that can or can influence a change in society, namely first, culture, and secondly the process of socialization that internalizes norms and values into actors. Normatively, what unites people together is a group of shared ideas. So the position of religious leaders in one community in socio-religious life has never been rivaled, in uniting and building communities in the surrounding environment. In that context, religious issues, religious attitudes are also used as jargon to build practical political alliances.
\end{abstract}

Keywords: Islamic Radicalism, Networks, Political Alliances, Community Response of Palu City

\section{Introduction}

The emergence of radical religious movements is an important phenomenon that has contributed to the image of contemporary Indonesian Islam. The appearance of movement 212 in 2017 which was originally an issue that is driven by religion intention in protest against the blasphemy case then in 2018 switched to political issues as an attitude of "hidden support " in the name of religion for a particular Presidential Election's candidate in the 2019 Presidential Election, as well as the strong reaction shown by the Hizbut Tahrir group over the case of the "tauhid flag" burning is a phenomenon of radical Islamic political movements under religious cloak that are should not be ignored in Indonesia.

At the beginning of this article, the authors need to clarify term "radical Islam" here, in contrast to what is understood in the Western world as a political Islamic movement that are often significantly negative and terrorists. Islam "radical " in this case is used to indicate the movement that fought basing pattern of life based on Islamic Sharia. This may be more correct to borrow from Umi Sumbulah's term, "radical" Islam does not always have a strong connotation in physical terms, but hard in terms of thoughts or discourse.[1]

The term 'radical Islam' as an integral part of the complex social and religious phenomena of Muslim groups in Indonesia is perhaps more appropriate to use here as a point of departure rather than as a labelling for an established and unchanging mention of the phenomenon. However, this 'identifying' position must be taken considering that sometimes a definition is made, such as the terms of 'radical Islam', 'revivalist Islam', or 'fundamentalist Islam', which are often problematic and stigmatic.[2]

In history, radical Islam has also been referred to Salafi-Jihadism, which are not entirely new symptoms. Muhammad bin Abdul Wahab with his Wahabiyah community is usually said to be a movement of radicalism or Islamic fundamentalism which has a long and wide impact. The Wahabi movement emerged as a reaction to the internal conditions of the Muslims themselves, 
not due to external factors such as Western penetration. Its emergence can be traced to the classic " Islamic political unrest" which ended in the fitnah al-Kubra. This incident gave rise to the Khawarij group who then opposed The Caliph Ali bin Abi Talib. They are the roots of the Islamic fundamentalist movement which takes the political path of opposition to the rightful rulers. The Khawarij, who were known to be radical and extreme, had aggravated the dispute between Caliph Ali bin Abi Talib and Mu'awiyah bin Abi Sofyan.

The question that arises then is what is the unique ideological colour of a 'radical Islam' movement? It should be noted that in some literature, the terms used to describe a contemporary phenomenon of fundamentalism in Islam are not uniform. Therefore, the term radical Islam is often used overlapping with the term fundamentalist Islam or revivalist Islam. John L Esposito, for example in his book Islam: the Straight Path (1988), Islam is a straight path. He prefers to use the term revivalist Islam to designate this contemporary Islamic movement. In general, borrowing Esposito's terminology[2], can be identified several ideological bases found in these movements, namely first, these groups argue that Islam is a comprehensive and total way of life. Thus, Islam cannot be separated from political life, law and society.

Second, they often think that the ideology of Western society which is secular and tends to be materialistic should be rejected. They also believe that Muslim societies have failed to build an ideal religious society because they have turned away from the straight path according to Islamic teachings by following this secular and materialistic Western perspective.

Third, they tend to invite their followers to return to Islam as an effort for social change. This change is only possible by fully adhering to authentic Islamic teachings such as the Qur'an and the Sunnah.

Fourth, because the ideology of Western society must be rejected, automatically social regulations that were born from Western traditions that have developed in Muslim societies as a legacy of colonialism must also be rejected. In return, the Muslim community must uphold Islamic law as the only accepted source of law.

Fifth, although many consider these groups to overly glorify the triumph of Islam in the past, which is reflected in the puritanical attitude of trying to implement a social and legal system appropriate to the time of the Prophet Muhammad, and clearly rejects modernization. At least they do not reject science and technology, insofar as these things do not contradict the standard religious orthodoxy they have taken to be established, and undermine what they consider to be final truth.

Sixth, they believe that Islamization efforts in Muslim societies will not succeed without emphasizing the aspect of organizing or forming a strong group. Although sometimes on a small scale, the groups that are built are usually ideologically strong in character, with rely partly on more educated and trained group members. In this way they can convince their followers to carry out sacred religious duties in order to uphold Islamic law or Sharia.

Looking at various more contemporary phenomena, that the movements sometimes go beyond some of the ideological grounds mentioned. There are at least some characteristics that we can identify why a group deserves to be called 'radical Islam'.

First, they still often display a 'Crusade' mentality. In the current context, the hegemony of the western world, especially the United States, against other nations is often seen as a form of 'new colonialism ' (neo-colonialism). Meanwhile, the idea of a Western conspiracy, which includes the Jewish Zionism movement against Islam and the Islamic world, continues to develop in this group.

Second. The enforcement of Islamic law which Muslim 'revivalists' and 'fundamentalists' often strive for is no longer considered an alternative way but has become a 'must'. In other words, there is no longer a valid way to form a Muslim community that truly 
submits to God, but instead makes Islam the basis for everything, including religious, social and political life.

Third, there is a tendency to fight against the government and its established systems but are not considered 'legitimate', especially because of the lack of attention to the problem of 'social disease' in society which they identify as 'immoral' and 'munkar'. Because of this, some of these groups no longer trust government legal institutions to deal with this. They believe that they are capable of coping with and fighting social ills itself and of course in their own ways regardless of the public sphere that becomes the context of Indonesia today. This is clearly seen in the Islamic Defenders Front (FPI) movement, Hizbut Tahrir Indonesia (HTI), and so on.

Fourth, the spirit to uphold religion as a symbol of the supremacy of the truth of God's teachings in the world by way of 'jihad' automatically gets a very respectable place. In fact, carrying out 'jihad' in all its aspects against evil and enemies who hate 'Islam' which they believe is a 'holy' religious duty. In fact, there is a very strong impression that 'jihad' is more interpreted as a physical effort to fight against the enemies of Islam.

Fifth, with the experience of witnessing the relationship between Islam and Judaism in disputes between Muslim and Jewish groups in the Palestinian region which is getting worse day by day, and the problem of conflict between Islam and Christianity that is still strong in several regions, including Indonesia, as well as the classic issue of Christianization. However, this relationship between Islam and Christianity significantly affects the perceptions of 'radical Islamic' groups. In this context, Jews and Christians no longer deserve to be considered as a group referred to in the Qur'an as 'people of the book' but have fallen as 'infidels' because the history of the two religions is identical to Western colonialism and Zionism. The two adherents of these religions are generally considered to have a united goal of conspiracy against Islam and the Islamic world.

It is important to note that some developments and even changes in the vision and orientation of this radical Islamic group also need to be examined more specifically. Oliver Roy in his work The Failure of Political Islam (1995), notes that there have been quite basic changes from similar movements in the Middle East. Realizing the failure of Muslim activists who wish to establish an Islamic State, Roy stated that today the issue of an 'Islamic state ' no longer excites this group. As a replacement, they are now appearing to emphasize more on a more substantive aspect of 'holy' ideals, namely through the implementation of Islamic law in society.

However, in line with Lawrence, according to Roy it does not mean that their desire to create an Islamic State has simply disappeared. When the social and political system becomes more conducive to reconciling this idea, the idea of an Islamic State is a dream that must be realized. In this context, an explanation of why some Islamic groups have voiced their desire for the implementation of Islamic law in Indonesia can be seen as a test case for the possibility of the establishment of an Indonesian Islamic State in the future.

The process of ideologizing religion in the Muslim world has occurred in a very broad context. Islam, which was originally an open minded, inclusive progressive belief, has shifted to a fundamental exclusion, from the traditional theological realm in the sociological field that formulated Islam into the norms and values of the socio-political order. Due to its ideological nature, Islam is finally understood as a belief about legitimacy consisting of interpretations of religious texts to be used in the socio-political realm. This may be legitimate, because religion itself does have moral and moral interests in political struggles.[3]

The presence of Islam as a political ideology as played by radical fundamental groups in Palu City, which appeared since the Emergency Response period due to the tsunami earthquake and the liquefaction of Palu, Sigi and Donggala (PASIGALA), Central Sulawesi in 2018. To strengthen their ideology and membership mobility, they established several foundations and has 
a number of schools such as SDIT (Integrated Islamic Primary School), SDIT Khalifah, TK and SD al-Qolam in Palupi and Tinggede Villages, Palu City. Apart from that they are also has a network of social mobility in raising funds for various purposes, including regarding earthquake tsunami and liquefaction Sigi Palu and Donggala (PASIGALA) through the One Care, Syam Organizer, Sahabat Sahlan, Qorratua'yun Foundation, and JKM

This article will explain the momentum of the emergence of networks of radical Islamic movements[4], political alliances, how to mobilize and show their existence and how the public response Palu against their existence.

\section{Literature Review}

According to the Major Indonesian Dictionary, the word radical contains three meanings; first, fundamentally (down to the principle): fundamental change, second, very loudly demanding change (law, government), and thirdly advancing in thinking or acting. Meanwhile, radicalism means; first, a radical ideology or flow in politics, second, an understanding or sect that wants social and political change or reform by means of violence or drastically, and third, an extreme attitude in the political stream.[5] Thus, radicalism is an attitude that crave a change in total and revolutionary with the overturning of values, the order of life, which is drastically through violence ( violence ) and extreme actions.

Bassam Tibi, explains the basic characteristics that stand out from radical Islamic circles or fundamentalists and may be considered as their characteristics or identity in general, namely:

First, fundamentalism has an aggressive agenda of politicizing religion and is carried out in order to achieve its goals. Second, fundamentalism, whether Islamic or otherwise, is a superficial form of terrorism or extremism.[6] An almost similar assessment was made by Richard T. Antoun. According to him, there are two main strategies of fundamentalists in order to develop their existence, namely; strategy of "exclusion and hijrah " (takfir wa hijrah) and their activity strategy which penetrated into confrontation strategies.[7] This first strategy presupposes a pattern of exclusion whether physical, social (in institutions, schools, churches, or political parties) or symbolic. Usually this tradition of symbolic separation is a strategy that is always applied. Here it seems Bassam Tibi identifies radical and fundamental meanings, especially in the symbolization and efforts of formalizing religion. This phenomenon can be shown in their dress code, behaviours, vocabulary (fundamentalist jargon; Allahu Akbar) or other rituals.

Meanwhile, strategies in the form of activism and totalism that penetrate toward confrontation can be demonstrated in the fundamentalist movement by establishing Islam as an alternative political ideology. One aspect of the totalistic confrontational strategy adopted by many fundamentalists is the pattern of using religion to become the ideology of the movement. Religion in this context acts as a means of legitimacy for confrontation and the achievement of the status quo.

It is important to note that, from a historical perspective, its emergence can be traced to the classic "Islamic political unrest" which culminated in the fitnah al-Kubra. Hence that, Mulyadhi Kartanegara, noted that there are at least 6 factors that may trigger the emergence of radicalism and terrorism, namely; thought, economics, politics, social, psychological, and education.[8] Kartanagara continued, is a fundamentalist, is religionists tend to the literal understanding of scripture against them. As for radicalists, namely groups/groups who like/want 
fundamental (radical) changes in the socio-political order. Meanwhile, terrorists are grouping whose policies or actions create intense fear.[8]

In the pre-modern period, the Wahabi movement represented itself or was seen by the majority of Muslims as Islamic fundamentalism under the leadership of Muhammad bin 'Abdul Wahab. Hasan Hanafi in his analysis said: the emergence of Islamic fundamentalism as constructed by Muhammad bin Abd Wahab was allegedly an expression of victory in defeating other tribes in the name of religious reformism, namely Wahhabism.[9] He emerged and became popular after Sa'ud's regime came to power in the country of Saudi Arabia. This early Islamic fundamentalism movement was nothing more than the result of the failure of the various tribal ritualism that had developed before King Sa'ud ascended the throne. Wahhabism is considered to exist in this Arab land, apart from being a source of religious-political legitimacy for the Saudi oil kingdom, the Saudi Monarchy in terms of state administration can be said to be conservative. By standing on the basis of Islamic legitimacy, Saudi Arabia has its own system of regulating the State and its people.

Indeed, before having physical or military strength, Wahabi generally committed doctrinal, intellectual and psychological violence by attacking anyone as idolatrous, apostate and infidel. However, after they had physical or military strength, the accusations were followed by physical attacks such as beatings, amputations, and killing of Sunni ulama or those who were not of their ideology. Wahhabis call all of this as da'wah,al-amr bi al-ma'ruf wa al-Nahy an alMunkar (inviting goodness and rejecting evil) and jihad, terms which actually do not have the connotation of violence in any form.

Similar phenomena have recently emerged in Indonesia, and it is difficult to deny the existence of a relationship or network between this phenomenon and Wahhabi ideology which has now become the official ideology of the Kingdom of Saudi Arabia and has been spread to the archipelago, including in Palu City and Central Sulawesi as a whole by agents or their collaborators with extraordinary financial support and systematic manner.

Among the relations between transnational fundamentalist movements (Salafi-Jihadism) operating in Nusantara-Indonesia are; first, the Muslim Brotherhood founded by Hasan al-Banna in Egypt was present in Indonesia initially through campus $d a^{\prime} w a h$ institutions which later became the Tarbiyah movement. This group later founded the Prosperous Justice Party (PKS); second, Hizbut Tahrir Indonesia (HTI) which carries the concept of Pan-Islamism and want to uphold the Islamic Caliphate throughout the world, and place the Indonesian Archipelago as a part of it; third, Wahabi who tried to do global wahabization. These three transnational movements work hand in hand in achieving their goals, namely the formalization of Islam in the form of a State and the application of sharia as positive law or Islamic Caliphate.[10] While other descendants such as the Indonesian Mujahidin Council (MMI) Abu Bakar Ba'asyir and Abdullah Sungkar (Salafi Islamic Boarding School Ngruki -Solo),[2] Laskar Jihad, apart from having Wahabi's gene, also has an "ideological genealogy" relationship with (NII 1949) by Soekarmadji Maridjan Kartosoewirjo (SMK), Daud Beureueh (DI / TII), Abdul Qahhar Mudzakkar (AQM) and Ahmad Husein from PRRI, who wanted to establish an Indonesian Islamic State.

\section{Discussion}


Palu City, inhabited by various religions and races (SARA). For example, ToKaili (Native), Bugis, Makassar, Mandar, Java, Ternate, China, Gorontalo, Manado, Lombok and Bali Mataram. However, To-Kaili still the majority population that inhabits not only the city of Palu, Donggala and Sigi, but also almost the entire region of Central Sulawesi Province. SARA's diversity also creates a diversity of cultures, customs and levels of education as well as employment opportunities in social life. Obviously, this diversity is a wealth and strength that must be maintained and empowered so that it can become a power source for the development of Palu City in a more advanced direction. Islam is the majority religion adhered to the total population of Palu. The distribution and percentage of population based on religion can be seen in the following table.

Table 1. Percentage of Population by Religion in Palu City, 2011-2 Percentage of Population by Religion in Palu Municipality, 2011-2015

\begin{tabular}{ccccccc}
\hline No & Religion & $\mathbf{2 0 1 4}$ & $\mathbf{2 0 1 5}$ & $\mathbf{2 0 1 6}$ & $\mathbf{2 0 1 7}$ & $\mathbf{2 0 1 8}$ \\
\hline $\mathbf{1}$ & Moslem & 80,05 & 85,21 & 89,33 & 80,67 & 84,06 \\
\hline $\mathbf{2}$ & Christian & 12,68 & 9,62 & 7,85 & 9,84 & 8,16 \\
\hline $\mathbf{3}$ & Catholic & 2,48 & 2,64 & 1,4 & 2,68 & 2,23 \\
\hline $\mathbf{4}$ & Hinduism & 2,42 & 0 & 1,02 & 2,44 & 2 \\
\hline $\mathbf{5}$ & Budism & 2,37 & 2,53 & 0,4 & 4,37 & 3,55 \\
\hline & TOTAL & $\mathbf{1 0 0}$ & $\mathbf{1 0 0}$ & $\mathbf{1 0 0}$ & $\mathbf{1 0 0}$ & 100 \\
\hline
\end{tabular}

Source : Ministry of Religious Affair of Palu

Table 2. Number of Places of Worship by District in Palu City, 2015

\begin{tabular}{|c|c|c|c|c|c|c|}
\hline & Kecamatan/ & Islam/ Moslem & $\begin{array}{l}\text { Kristen/ } \\
\text { Christian }\end{array}$ & $\begin{array}{l}\text { Katholik/ } \\
\text { Catholic }\end{array}$ & $\begin{array}{l}\text { Hindu/ } \\
\text { Hinduism }\end{array}$ & $\begin{array}{l}\text { Budha/ } \\
\text { Buddhisı }\end{array}$ \\
\hline & Subdistrict & $\begin{array}{l}\text { Masjid/Surau/ } \\
\text { Mosque /Mini }\end{array}$ & $\begin{array}{l}\text { Gereja/ } \\
\text { Church }\end{array}$ & $\begin{array}{l}\text { Gereja/ } \\
\text { Church }\end{array}$ & Pura/ Temple & $\begin{array}{l}\text { Wihara/ } \\
\text { Temple }\end{array}$ \\
\hline & (1) & (2) & (3) & (4) & (5) & (6) \\
\hline 01 & Palu Barat & 70 & 12 & 5 & - & - \\
\hline 02 & Tatanga & 50 & 5 & - & - & - \\
\hline 03 & Ulujadi & 49 & 7 & 1 & - & - \\
\hline 04 & Palu Selatan & 75 & 9 & 66 & 1 & - \\
\hline 05 & Palu Timur & 45 & 9 & 12 & 1 & - \\
\hline 06 & Mantikulore & 85 & 12 & 1 & - & 2 \\
\hline 07 & Palu Utara & 85 & 6 & 5 & - & - \\
\hline 08 & Tawaeli & 36 & 5 & 2 & - & - \\
\hline
\end{tabular}




\begin{tabular}{lllllll}
\hline $\mathbf{2 0 1 4}$ & 308 & 71 & 86 & 2 & 2 & 5 \\
\hline $\mathbf{2 0 1 3}$ & 317 & 99 & 83 & 2 & 1 & 1 \\
\hline $\mathbf{2 0 1 2}$ & 275 & 40 & 83 & 2 & 4 & 4 \\
\hline $\mathbf{2 0 1 1}$ & 348 & 70 & 83 & 2 & & 1 \\
\hline
\end{tabular}

Source: Ministry of Religious Affair of Palu

Based on the data in the two tables above, both from the aspect of the number of religious adherents and the distribution of places of worship, it is clear that the majority of the Muslim community is internally, although not recorded in the table, if it is mapped based on organizational trends, ideology and figh schools, it can be said that the majority of them are scattered into several social organizations and religious institutions consisting of; Alkhairaat (1930), Nahdlatul Ulama (NU-1926), Muhammadiyah (1916), and Daruddakwah Wal Irsyad (DDI-1933). The rest are scattered into small groups such as; The Indonesian Islamic Da'wah Institute (LDII), Al- Wahdah, Syi'ah, and HTI itself.

When analysed the distribution of the Muslim community in Palu City using a historical approach, especially the history of the national consensus on the early establishment of the Unitary State of the Republic of Indonesia (NKRI), several of these organizations, both NU, Muhammadiyah, Alkhairaat, and DDI, have "ideological services to the Republic of Indonesia " which cannot be forgotten throughout the history of Indonesia. National history records that a number of figures from several of these mass organizations agreed with Pancasila as the basis and ideology of the Republic of Indonesia. It is for a Muslim community like this that the radical groups in Palu City including HTI offer a Khilafah Islamiyah state, replacing Pancasila.[11] In this context, we can imagine what the response would be and the perception of the Muslim community in Palu City towards the mobilization of membership in radical groups, the HTI campaign. The following discussion will describe the mass mobilization carried out by the network of radical groups including HTI as the dominant group in the network.

1. In Palu City and Central Sulawesi, HTI was first established in 2004 led by Ustadz Amirudin (2004-2010 period), then led by Ustadz Sardi Ibn Arsy (2010-present period). HTI began to be registered with Kesbangpol Central Sulawesi Province in 2014, which shows that their existence is legal. The emergence of HTI in Palu City and Central Sulawesi as a whole cannot be separated or is a direct influence of the dynamics of HTI nationally in Jakarta and in various cities in the Republic of Indonesia. For example; 2000 International Khilafah Conference, 2007 International Khilafah Conference, 2009 National Ulema Conference, Indonesian Muballighah Conference in 2010, and the Rajab Conference in 2011.[12] In the first stewardship period (2004-2010) the HTI movement was more focused on socialization, member recruitment, infrastructure development, cadre and formation of pockets of movements that are considered strategic for the development of HTI in Palu and Sulawesi City Middle. Like the Muslim Brotherhood (IM), HTI takes the campus as the basis of the movement that supports all the activities they carry out. And from the campus, which is usually centred on the campus mosque, HTI conducts training and cadre for its members.

Meanwhile, in the period of the management of Ustadz Sardi Ibn Arsy (2010-present), the HTI movement in Palu City, apart from still being focused and continuing the movements of the previous period, also began to expand its progress and movement orientation. For example, expanding networking. This was done by visiting several figures and scholars, including visiting Habib Ali bin Muhammad Aljufri, Chairman of PB Alkhairaat and Chairman of the Central Sulawesi MUI, Ustadz Jamaluddin Hadi, preachers and Muhammadiyah figures. According to Sardi, this was done not only so that HTI could get 
input from the ulama and figures from these Islamic organizations, as well as so that the ulama could find out what HTI was fighting for.[12]

In addition to the agenda of gathering to ulama, HTI also conducts dialogue and communication with high school students and students in schools and several state and private universities in Palu City. In addition, in order to fikrah and their mission to spread widely, then they spread Bulletin Dakwah Al-Islam every Friday in the Jum'ah prayer. This bulletin is printed with various actual themes, including:

a. Al-Islam, ed. 764, 23 Ramadhan 1436 H / 10 July 2015 M. Reflections to welcome Eid: "Together with the Ummah, uphold the Khilafah Ar - Rasyidah".

b. Al-Islam, ed. 772, 4 Dzulhijjah 1436 H / 18 September 2015 M. "Khilafah: Creating Obedience, Uniting the Ummah (Eid Al-Adha Reflection 1436 H / 2015 M).

c. Al-Islam, ed. 805, 28 Rajab 1437 H / 6 May 2016 M. Rajab's reflections: "Khilafah: Mandatory Sharia, Needed by the Ummah".

d. Al-Islam, ed. 806, 6 Sya'ban 1437 H / 13 May 2016 M. "As a result of Shari'ah not being applied, women are also victims ".

e. Al-Islam, ed. 809, 27 Sya'ban 1437 H / 3 June 2016 M. "Ramadan: Time to Realize Kaffah Islam ".

f. Al-Islam, ed. 822, 14 Dzulhijjah 1437 H / 14 September 2016 M. "Beware of Confusion of Meaning of Kafir and Faith ".

g. Al-Islam, ed. 824, 27 Dzulhijjah 1437 H / 30 September 2016 M. "Hijrah, Time to Change".

h. Al-Islam, No. 825, 6 Muharram 1438 H / 07 October 2016 M. "Superstition And Khurafat Grows Massively in a Secular Society".

i. Al-Islam, No. 826, 13 Muharram 1438 H / 14 October 2016 M. "Act Strictly for Qur'an Blasphemy!".

The distribution of the Al-Islam bulletin is one of the ways HTI has always used to market and publish their ideas, including "the obligation to uphold the Islamic Caliphate ". There are two key words that have always been put forward by HTI activists when discussing the Caliphate state, namely, "Shari'ah and Caliphate", these two Islamic political keywords are the breath of HTI in the context of upholding the Islamic Caliphate.

For HTI, as noted in several manifestos of their world political view, it is emphasized that the Islamic Caliphate is an ideological state, and its main task is to develop Risalah Islamiyah throughout the world. So, it is obligatory on it, and it is included in its existence to have a high position on the international stage and strive to influence relations between nations. It must not be denied that the concept of politics in political science must be from the concept between nations and not one-off or local one. So Muslim political experts must have a political concept of international rank apart from the concept of local. So, they have a great responsibility in having a perfect and comprehensive political awareness. As a Muslim individual and an Islamic state, the basic and written roles are developing Islam throughout the world, and this requires a comprehensive political awareness.[13]

It seems that HTI circles are very aware that one of the methods to publicize the desire to establish or enforce the Islamic Caliphate state, including changing and shaping the people's way of thinking, through reading media. Apart from the bulletin, the magazine al$W a^{\prime} i$ - Political Media and Da'wah, is also always marketed and disseminated to the Muslim community in Palu City. The al- Wa'i media, has a much wider and more varied segment and presentation of studies than the Al-Islam bulletin. 
2. In Palu City, several points of movement of radical Islamic networks were found. In addition to mobilizing membership at the community level by conducting routine recitations at several good points in the mosque, it also uses the office facilities of government agencies. For example, inviting speakers of radical figures in their study activities but not regularly. Meanwhile, those who regularly fill in the study, especially at Masjid al-Taubah the BPKB complex and the al-Munawaroh Mosque, the Agriculture Office complex at jl. Kartini.

Meanwhile, the study activities outside government offices such as the al-Taubah Mosque in the Pelangi alley, the Jalan Bangau Putih Mosque, the Nurul Iman Mosque next to the Palu III Bridge, and one of the small mosques in Kalikoa Village, West Palu District.

To strengthen their ideology and membership mobility, they established several foundations and owned a number of schools such as; SDIT Alfahmi, SDIT in the border housing of Palupi Village and Tinggede Village namely SD Al-Qolam and TK al-Qolam Palupi, Qorratua'yun Foundation, SDIT Khalifah. These schools for certain subjects such as Islamic religious education, they have their own textbooks and do not use the Ministry of Religion textbooks.

Social mobility networks in raising funds for various purposes including caring for the tsunami earthquake and liquefaction of Palu Sigi and Donggala (PASIGALA) through One Care, Syam Organizer, Sahabat Sahlan, Qorratuayun Foundation, and JKM.

The roots of the networks of these groups are connected directly and indirectly to transnational radicalism/fundamentalism (Salafi-Jihadism) movements operating in the Indonesian Archipelago, such as;

a. Ikhwanul Muslimun (IM). Founded by Hasan al-Banna in Egypt, it was present in Indonesia through campus's da'wah institutions which later became the Tarbiyah movement.

b. HTI (HT). HTI together with IM founded the Justice Party (PK) which has now turned into the Prosperous Justice Party (PKS). The jargon carries the Caliphate State throughout the world, and places Indonesia as a part of it.

c. Wahabi who tried to carry out global wahabization. These three transnational movements work hand in hand in achieving their goals, namely the formalization of Islam in the form of a State and the application of shariah as positive law or the Islamic Caliphate.

While other descendants such as the Indonesian Mujahidin Council (MMI) Abu Bakar Ba'asyir and Abdullah Sungkar (Salafi Islamic Boarding School Ngruki - Solo), Laskar Jihad, apart from having a Wahabi gene, also has an "ideological genealogy" relationship with (NII 1949) by Sekarmadji Maridjan. Kartosoewirjo (SMK), Daud Beureueh (DI / TII), Abdul Qahhar Mudzakkar

(AQM) and Ahmad Husein from PRRI, they want to establish an Indonesian Islamic State. In the perspective of the State, the issue of radicalism is not only considered an anxiety of the people of the nation but has also become a threat to the integrity of the Unitary State of the Republic of Indonesia.

Tadulako University Campus Network (UNTAD), especially in student networks, radical Islam enters through the Student Organization Lovers of Mosques or Musalla and LDK UPIM Tadulako University (Untad), so it is not uncommon for the Untad complex mosque to invite several speakers from radical groups.[14] The radical network actors who entered the campus of the State Islamic Institute (IAIN) in Palu, came from the UNTAD or LDK UPIM network. It's just that their activities are not too prominent because there are balancing organizations that are moderate in nature besides UKM, which are also always 
controlled by the ANSOR Youth Movement, Muhammadiyah Youth and PMII. Below can be seen some of the actors driving the UNTAD network; Andi Baso Satria Kurniawan (HTI), activist of MPM Darussalam Faculty of Law. Aminuddin (HTI figure), lecturer at the Faculty of Agriculture UNTAD, former Chairman of UPIM UNTAD. Advisor of MPM Faculty of Agriculture. Saldi Aras.S.Pd (Chairman of PW HTI Central Sulawesi), former Chairman of the MPM. FKIP, here is the basis for HTI cadre.

\section{Conclusion}

The city of Palu, inhabited by various ethnic groups, religions and races (SARA), consists of ethnic groups; To-Kaili (indigenous people), Bugis Makassar, Mandar, Java, Ternate, China, Gorontalo, Manado, Lombok-Mataram and Bali. However, To-Kaili, is the majority population who inhabit almost the entire region of Central Sulawesi. SARA's diversity also creates a diversity of cultures, customs and levels of education as well as employment opportunities in social life. The majority of Palu City residents are Muslim. When mapped based on the organizational tendencies, ideologies and fiqh schools adopted, the Muslim community is scattered into social organizations and religious institutions; Alkhairaat (1930), Nahdlatul Ulama (NU-1926), Muhammadiyah (1916), and Daruddakwah Wal Irsyad (DDI-1933). The rest are scattered into small groups such as; The Indonesian Islamic Da'wah Institute (LDII), AlWahdah, Wahabi, Syi'ah, and HTI itself. Based on the history of the national consensus of the establishment of the Unitary State of the Republic of Indonesia (NKRI), these organizations approved Pancasila as the basis of the Republic of Indonesia. Therefore, they have a psychological distance from the tendency of radical Islamic schools to blame and infidel Muslims, including the idea of a Caliphate state brought by Hizbuttahrir Indonesia.[15]

At the campus level, especially Tadulako University, the Student network, radical Islam entered through the Student Organization Loving the Mosque or Musalla and the UPIM University of Tadulako (Untad) LDK, so it was not uncommon for the Untad complex mosque to invite several lecturers from radical groups. There are parts of the community who are accommodating as a response to several educational institutions established by radical Islamic groups, so that there are some people who send their children to these schools. This accommodative attitude is caused by two things: first, lack of understanding of the mission of radical teachings developed by these institutions, second, too fascinated with the stretching or progress of the school developed by the group.

In Palu City, several points of movement of radical Islamic networks were found. In addition to mobilizing membership at the community level by conducting routine recitations at several good points in the mosque, it also uses the office facilities of government institutions. For example, inviting speakers of radical figures in their study activities but not routinely. Meanwhile those who routinely fill in the study, especially at the al-Taubah Mosque, the BPKB complex and the al-Masjid al- Munawaroh Agricultural Office complex Jl. Kartini. Meanwhile, outside government offices such as the al-Taubah Mosque in the Rainbow hall, the Bangau Street Mosque Putih, a mosque beside the Palu III Bridge, and one of the small mosques in Kalikoa Village, West Palu District.

To strengthen their ideology and membership mobility, they established several foundations and owned a number of schools such as; SDIT Alfahmi, SDIT in the border housing of Palupi and Tinggede villages, namely Al-Qolam Elementary School and Al-Qolam Palupi Kindergarten, Qorratua'yun Foundation, SDIT Khalifah. These schools for certain subjects such 
as Islamic religious education, they have their own textbooks, not using textbooks printed by the Ministry of Religion. Social mobility networks in raising funds for various purposes including caring for the tsunami earthquake and liquefaction of Palu Sigi and Donggala (PASIGALA) through One Care, Syam Organizer, Sahabat Sahlan, Qorratuayun Foundation, and JKM.

The roots of the network of these groups are connected directly and indirectly to transnational radicalism/fundamentalism (Salafi-Jihadism) movements operating in the Indonesian Archipelago, such as; Ikhwanul Muslimun (IM). Founded by Hasan al-Banna in Egypt, it was present in Indonesia through campus da'wah institutions which later became the Tarbiyah movement. HTI (HT). HTI together with IM founded the Justice Party (PK) which has now turned into the Prosperous Justice Party (PKS). The jargon carries the Khilafah State throughout the world, and placing Indonesia as a part of it. Wahabi who tried to carry out global wahabization. These three transnational movements work hand in hand in achieving their goals, namely the formalization of Islam in the form of a State and the application of shari'ah as positive law or Khilafah Islamiyah. While other descendants such as the Indonesian Mujahidin Council (MMI) A bu Bakar Ba'asyir and Abdullah Sungkar (Salafi Islamic Boarding School Ngruki -Solo), Laskar Jihad, apart from having a Wahabi gene, also has an "ideological genealogy" relationship with (NII 1949) by Sekarmadji. Maridjan

Kartosoewirjo (SMK), Daud Beureueh (DI / TII), Abdul Qahhar Mudzakkar (AQM) and Ahmad Husein from PRRI, they want to establish an Islamic State of Indonesia.

\section{References}

[1] S. Umi, Islam "Radikal” dan Pluralism Agama Studi Konstruksi Sosial Aktivis Hizb alTahrir dan Majelis Mujahidin di Malang tentang Agama Kristen dan Yahudi, Seri Diser. Jakarta: Badan Litbang dan Diklat Kementerian Agama RI, 2010.

[2] Jamhari and and Jahroni Jajang, Gerakan Salafi Radikal di Indonesia, First Edit. 2004: PT. Raja Garafindo Persada.

[3] A. M. and Abegebriel and A. Yani Abeveiro, Negara Tuhan The Thematic Encyclopedia, 1st ed. Jogjakarta: SR-INS Publishing, 2004.

[4] "Observation and Premilinar investigation conducted by the author was to detect places and mobility post of radical group in Palu, since the Emergency time as the response of natural disaster, tsunami and liquefaction of Palu Sigi and Donggala," PASIGALA, 2018.

[5] "Kamus Besar Bahasa Indonesia.".

[6] B. Tibi, The Challenge of Fundamentalism Political Islam and the New World Disorder. California, 1998.

[7] R. T. Antoun, Memahami Fundamental: Gerakan Islam, Kristen, Yahudi. Surabaya: Pustaka Eureka, 2002.

[8] M. Kartanegara, "Fundamentalisme, Radikalisme dan Terorisme: Sebab dan Solusinya dari Perspektif Pemikiran dan Pendidikan Islam,” Jakarta, 2012.

[9] H. Hanafi, “Asal Usul Konservatisme Keagamaan dan Fundamentalisme Islam,” Ulumul Quran, vol. II, p. 7.

[10] A. Wahid, Ilusi Negata Islam-Ekspansi Gerakan Islam Transnasional di Indonesia, Cetakan I. Jakarta: Diterbitkan atas kerjasama Gerakan Bhinneka Tunggal Ika, The Wahid Institute dan Maarif Institute, 2009.

[11] A. G. Jumat, Nasionalisme Ulama: Pemikiran Politik Kebangsaan Sayyid Idrus bin 
Salim Aljufri 1891-1969, Seri Diser. Jakarta: PUSLITBANG Kementerian Agama RI, 2012.

[12] "Sardi Ibn Arsyi, Head of DPW HTI Sulawesi Tengah Zaharudin, Ketua HTI Kota Palu," 2016.

[13] "Manivesto Konsep Politik Hizbuttahrir Document 3," 1969.

[14] R. Atma, "(alumni Fakultas Hukum UNTAD), Wawancara tanggal 17 Oktober 2019 di Palu."

[15] M. S. Al-DJufri, Wahdah Islamiyah Di Gorontalo (Studi Tentang Corak Pemikiran dan Respon Masyarakat), Seri Diser. Jakarta: PUSLITBANG Kementerian Agama RI, 2011. 